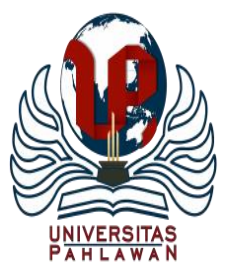

Edukatif : Jurnal Ilmu Pendidikan Volume 3 Nomor 5 Tahun 2021 Halm 3131 - 3144

EDUKATIF: JURNAL ILMU PENDIDIKAN

Research \& Learning in Education

https://edukatif.org/index.php/edukatif/index

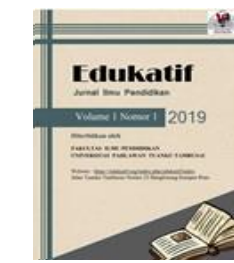

Pengembangan Macromedia Flash Berbasis Keterampilan Berpikir Kritis di Sekolah Dasar

\author{
Yulia Ulfa $^{1 凶}$, Prima Mutia Sari²
}

Universitas Muhammadiyah Prof. Dr. HAMKA, Indonesia ${ }^{1,2}$

E-mail : ulfaayulia@gmail.com ${ }^{1}$, primamutiasari@uhamka.ac.id ${ }^{2}$

\begin{abstract}
Abstrak
Penelitian ini dilakukan untuk menganalis kualitas serta kelayakan dari sebuah media pembelajaran Macromedia flash berbasis keterampilan berpikir kritis pada pembelajaran IPA berkaitan dengan materi Cuaca di kelas III SD. Metode penelitian yang digunakan adalah kualitatif dan kuantitatif menggunakan research and development(R\&D). Subjek penelitian ini adalah SDS Muhammadiyah 4 Jakarta kelas III berjumlah 12 orang dan seorang guru. Pengembangan media pembelajaran Macromedia flash berbasis keterampilan berpikir kritis menggunakan model ADDIEyang diuji cobakan kepada guru dan siswa kelas III SD Muhammadiyah 4 Jakarta. Hasil produk akhir, yaitu file dengan format .exe atau application, yang terdiri dari materi cuaca dengan submateri keadaaan cuaca, perubahan cuaca, dan dan pengaruh perubahan cuaca terhadap kehidupan manusia. Hasil dari validasi ahli materi didapatkan skor dengan presentasi sebessar $82.66 \%$ dengan kategori sangat layak. Hasil dari validasi ahli media didapatkan skor dengan presentasi sebessar $80.00 \%$ dengan kategori sangat layak. Respon guru terhadap media pembelajaran dilihat dari hasil angket mendapatkan skor presentase sebesar $94.66 \%$ dengan kategori sangat layak. Respon siswa terhadap media pembelajaran dilihat dari hasil angket yang diberikan diberikan mendapatkan skor presentase sebesar $94.00 \%$ dengan kategori sangat layak. Berdasarkan hasil data yang telah diperoleh menunjukkan bahwa Macromedia flash berbasis keterampilan berpikir kritis pada materi Cuaca di kelas III SD layak digunakan sebagai media pembelajaran di kelas III SD.
\end{abstract}

Kata Kunci: Pendidikan, Media Pembelajaran, Berpikir Kritis,

\begin{abstract}
This study aims to determine the quality and feasibility of learning media Macromedia flash based on critical thinking skills on Weather material in grade III SD. The research method used is the qualitative and quantitative method using research and development $(R \& D)$. The subjects of this study were SDS Muhammadiyah 4 Jakarta class III totaling 12 people and a teacher. Development of learning media Macromedia flash based on critical thinking skills using the ADDIE model which was tested on third-grade teachers and students at SD Muhammadiyah 4 Jakarta. The final product is a file with .exe or format application, which consists of weather material with sub materials of weather conditions, weather changes, and the effect of weather changes on human life. The results of the material expert validation obtained a score with a presentation of $82.66 \%$ with a very decent category. The results of the media expert validation obtained a score with a presentation of $80.00 \%$ with a very decent category. The teacher's response to the learning media seen from the results of the questionnaire got a percentage score of $94.66 \%$ with a very decent category. Student responses to learning media seen from the results of the questionnaire given were given a percentage score of $94.00 \%$ with a very decent category. Based on the results of the data that has been obtained, it shows that Macromedia flash based on critical thinking skills on Weather material in class III SD is suitable for use as a learning medium in class III SD.
\end{abstract}

Keywords: Education, Learning Media, Critical Thinking.

Copyright (c) 2021 Yulia Ulfa, Prima Mutia Sari

$\triangle$ Corresponding author:

Email : ulfaayulia@gmail.com

DOI : https://doi.org/10.31004/edukatif.v3i5.1235

ISSN 2656-8063 (Media Cetak) ISSN 2656-8071 (Media Online) 


\section{Pengembangan Macromedia Flash Berbasis Keterampilan Berpikir Kritis di Sekolah Dasar - Yulia}

Ulfa, Prima Mutia Sari

DOI: https://doi.org/10.31004/edukatif.v3i5.1235

\section{PENDAHULUAN}

Perkembangan yang masif teknologi dan komunikasi (TIK) pada abad ke-21 ini berpengaruh secara signifikan terhadap segala aspek kehidupan manusia, tak terkecuali pendidikan. Oleh sebab itu, pendidikan perlu ditingkatkan guna mewujudkan sumber daya manusia maupun lulusan yang secara kualitas mumpuni untuk bertahan menghadapi berbagai tantangan yang ada. Dengan berkembangnya TIK dalam dunia pendidikan berimplikasi pada berubahnya pola pembelajaran yang dilakukan pada semulanya berpusat pada guru kini mulai berorientasi pada peserta didik. Hal ini reformasi sistem pendidikan yang terlihat jelas pada abad ke-21. Pembelajaran abad-21 merupakan sebuah tantangan baru dalam dunia pendidikan.Pendidik dan peserta didik wajib mempunyai keterampilan belajar dan mengajar abad-21, agar sumber daya manusia yang dihasilkan cakap dan tanggap terhadap perkembangan zaman.Keterampilan-ketarampilan yang dimaksud yaitu, keterampilan 4C (Critical Thinking, Communication, Collaboration, dan Creativity)(Sholikha \& Fitrayati, 2021) Hal ini mengindikasikan bahwa kemampuan kritis menjadi salah-satu kemampuan yang secara fundamental dibutuhkan.

Keterampilan berpikir kritis dapat didefinisikan sebagai kemampuan seseorang dapat mengambil keputusan dengan berpikir secara logisdan efektif dengan tujuan untuk memecahkan permasalahanpermasalahan yang timbul dalam kehidupan sehari-hari sehingga pertanggungjawaban dapat dilakukan atas keputusan yang diambil(Widowati \& Purwanto, 2018). Hal ini telah dimasukan ke dalam standar kurikulum yang berlaku yaitu kurikulum 2013. Dalam keterampilan berpikir kritis tentunya terdapat indikator-indikator penentu dimana peserta didik dapat dikatakan berpikir kritis, yaitu pada saat prosespengamatan, tanya-jawab, percobaan, pengolahan, penalaran, dan komunikasi yang terjalin antara tenaga pendidik dan peserta didik(Maryam et al., 2020). Mengingat pentingnya, hal tersebut, keterampilan berpikir kritis peserta didik perlu diasah agar peserta didik dapat memberdayakan emampaun berpikir kritis untuk merumuskan solusi atas permasalah yang timbul dalam kehidupan sehari-hari(Suhartini \& Martyanti, 2017). Berpikir kritisdiperlukan adanya inepretasi dan evaluasi sumber informasi yang didapatkan(Fridanianti et al., 2018). Berpikir kritis juga dapat disebut dengan berpikir yang reflektif dan rasional secara mendalam (menganalisa situasi dan informasi) guna mengambil keputusan serta kesimpulan yang tepat. Untuk itu, perlunya langkah strategis yang dilakukan individu untuk mengasah kemampuan berpikir kritis mereka dalam setiap pengambilan keputusan(Munawwarah et al., 2020). Faktor yang mempengaruhi kemampuan berpikir kritis seseorang antara lain faktor psikologi seperti perkembangan intelektual, motivasi, dan kecemasan. Selain itu, kemampuan berpikir kritis juga dipengaruhi oleh faktor fisiologi seperti kondisi. Faktor lainnya yang turut mempengaruhi yaitu faktor kemandirian belajar dan faktor interaksi(Daroes et al., 2020). Fase dari proses berpikir kritis juga dibedakan menjadi fase internalisasi dan fase setelah internalisasi. Maka dalam hal ini, kemampuan ini dapat dikembangkan. Salah satu bidang ilmu yang seringkali membutuhkan keterampilan berpikir kritis yang berhubungan dengan kehidupan manusia yaitu Ilmu Pengetahuan Alam (IPA).

IPA dapat didefinisikan sebagai sebuah bidang ilmu yang berhubungan dengan ilmu pengetahuan alam atau yang membahas tentang kejadian-kejadian yang berada di alam. IPA merupakan pengetahuan yang objektif dan rasional(Lestari, 2018). IPA merupakan proses yang menghasilkan dari pengumpulan data dengan cara melakukan eksperimen, deduksi, dan pengamatan sehingga menghasilkan pengetahuan mengenai suatu gejala(Umryaty, 2020). Pembelajaran IPA merupakan suatu proses yang membelajarkan peserta didik dalam mempelajari pentingnya suatu pristiwa atau gejala alam yang terjadi di lingkungan alam (Mutmainnah et al., 2020).Cuaca merupakan salah satu kajian yang dapat dipelajari melalui mata pelajaran ini. Sesuai dengan pembelajaran di abad-21, dimana guru berperan sebagai fasilitator sedangkan proses pembelajaran sendiri berpusat pada peserta didik, mengingikasikan bahwa peran guru sangat krusial dan esensial dalam proses pemberlajaran. Materi yang ada pada pelajaran IPA banyak konsep yang bersifat abstrak hingga konseptual memerlukan media pembelajaran yang dapat menyokong pemahaman peserta didik atas materi yang 


\section{Pengembangan Macromedia Flash Berbasis Keterampilan Berpikir Kritis di Sekolah Dasar - Yulia Ulfa, Prima Mutia Sari}

DOI: https://doi.org/10.31004/edukatif.v3i5.1235

dipelajari(Syamsuddin, 2020). Dengan berkembangnya dari TIK sendiri, mewajibkan setiap proses pembelajaran dimana guru selaku perencana pembelajaran harus disusun kreatif dan inovatif dengan menggunakan, memanfaatkan, mengembangkan dan mengkaitkan teknologi dalam kegiatan belajar-mengajar secara menyeluruh. Hal ini bertujuan agar peserta didik mampu mengembangkan potensi dan keterampilan di dalam diri peserta didik. Pembelajaran inovatifdan kreatif dapat dilakukan dengan cara mengembangkan komponen-komponen pembelajaran(Fridanianti et al., 2018). Setelah menggunakan media pebelajaran yang inovatif dan kreatifpeserta didik diupayakan untuk menunjukan tiap indikator berpikir kritis, antara lain: mampu memberikan penjelasan yang sederhana mengenai pemahamannya terhadap suatu informasi, membangun dan mengembangkan keterampilan dasar yang diperoleh melalui proses belajar, menyimpulkan suatu informasi, mampu memberikan penjelasan lebih lanjut berkkaitan dengan suatu informasi, dan mengatur taktik dan strategi(Wijayanti \& Siswanto, 2020).

Media pembelajaran merupakan salah-satu komponen yang fundamental dalam menyukseskan agenda pemberlajaran yang dilakukan. Terdapat enam jenis media pembelajaran, salah satunya yaitumultimedia berbasis komputer dan interaktif video (Khuluqo, 2017).Media pembelajaran juga dapat didefinisikan sebagai alat yang menyokong proses belajar mengajar agar pesan atau makna yang coba diberikan dalam proses ini dapat diterima dan diproses dengan baik oleh peserta didik. Manfaat media pembelajaran juga beragam. Salah -satunya adalah membangkitkan motivasi belajar pada peserta didik(Rohani, 2019). Pada perkembangan teknologi saat ini tentunya media pembelajaran dapat dibuat lebih inovatif dan kreatif. media pembelajaran tidak lagi berbentuk media satu arah, hal ini dapat dilihat dari banyaknya program aplikasi maupun Software yang dapat mendukung pembuatan media pembelajaran interaktif berbasis komputer dan interaktif video sepertiMacromedia Flash. Macromedia Flashadalah salah-satu aplikasi atau software yang dapat membantu guru dalam mengembangakan media pembelajaran interaktif atau dua arah. Kelebihan dari Macromedia Flash selain dapat membuat media pembelajaran interaktif, yaitu dapat menampilkan multimedia, menggabungkan teks, video, suara, grafis, dan animasi. Pada pembeajaran abad-21 ini, salah satu keterampilan guru yang diperlukan adalah menggunakandan memanfaatkan teknologi pada setiap proses pembelajaran guna menarik minat dan motivasi peserta didik dalam belajar sehingga dapat membantu untuk meningkatkan keterampilan berpikir peserta didik(Nissa \& Renoningtyas, 2021).

Dalam perkembangan dunia pendidikan saat ini, belajar dari rumah merupakan metode yang kini diterapkan di banyak negara, termasuk Indonesia. Hal ini mengingat penyebaran pandemi COVID-19 yang mudah. Kebijakan ini berimplikasi bahwa pembelajaran di sekolah oleh guru terkesan monoton, Pembelajaran hanya menggunakan video berupa slide Powerpoint dengan metode ceramah dibantu dengan audio atau perekam suara. Hal ini jauh dari tujuan pendidikan yang berupaya untuk mengembangkan kemampuan kritis peserta didik. Untuk itu, intevensi media pembalajaran menjadi krusial dalam halini. Penggunaan media pembelajaran dengan Macromedia Flashdapat dapat menjadi solusi bagi guru dalam mengembang kan media pembelajaran interaktif atau dua arah. Hasil dari penelitian sebelumnya yang telah diteliti, dinyatakan bahwa dengan menggunakan media atau Software Macromedia Flash pada pembelajaran berbasis kemampuan berpikir kritis peserta didik, memenuhi kriteria kelayakan sangat baik untuk digunakan pada proses pembelajaran (Amalia et al., 2020). Dalam penelitian sebelumnya ditemukan bahwa kelebihan dari macromedia flash antara lai: menekankan pada interaktivitas, kualitas gambar yang baik, dapat dipadukan dengan software lainnya, mudah menginisiasi adanya animasi, terdapat loading time, dapat diintegrasikan dengan program lainnya, dapat mengimport semua jenis file, ukuran yang lebih kecil, dapat digunakan untuk berbagai macam tujuan, dan dapat disimpan dalam berbagai macam format. Sedangkan kekurangannya seperti harus tersedianya script, dibutuhkannya referensi, dan kurang dalam animasi 3D(Haeruddin, 2017).

Dalam penelitian ini, peneliti juga menganalisis beberapa penelitian sebelumnya yang terkait mengungkapkan bahwa peran media pembelajaran dan korelasinya dengan keterampilan berpikir kridi. Media Pembelajaran berupa prezi terbukti ampuh untuk meningkatkan kemampuan berpikir kritis peserta didik 


\section{Pengembangan Macromedia Flash Berbasis Keterampilan Berpikir Kritis di Sekolah Dasar - Yulia}

Ulfa, Prima Mutia Sari

DOI: https://doi.org/10.31004/edukatif.v3i5.1235

dalam materi pembelajaran IPA yaitu sistem pernapasan makhluk hidup. Dalam penelitian ini media yang dipilih memenuhi kriteria kelayakan baik dalam segi tampilan media maupun materi dengan kategori sangat layak digunakan yang telah divalidasi atau dinilai oleh validator (Widowati \& Purwanto, 2018).

Penelitian sebelumnya juga menemuan babhwa Multimedia Lectora Inspire secara signifikan berimplikasi pada peningkatan keterampilan peserta didik dalam berpikir kritis. Hal ini ditunjukan dengan upaya yang dilakukan dalam menyelesaikan soal bangun ruang. Hasil penelitian validitas, penilaian kepraktisan media, dan keefektifan media dinyatakan valid dan layak untuk digunakan dalam menyelesaikan soal cerita bangun ruang pada pemebelajaran matematika kelas V (Muttaqin et al., 2020).

Kemudian penelitian tentang Media Pembelajaran PMRI juga terbukti mampu meningkatkan keterampilan berpikir kritis pasa peserta didik di jenjang SMP. Penelitian ini menemukan bahwa media PMRI memenuhi kriteria kelayakan sangat baik untuk digunakan yang telah dinilai dan divalidasi oleh validator (Amalia et al., 2020).

Penelitian yang mengembangkan Macromedia Flash dalam pembelajaran dapat menarik minat dan motivasi peserta didik. Telah diungkap bahwa pembelajaran abad 21 menekankan pada proses keterampilan belajar, terutama keterampulan berpikir kritis. Dari fenomena tersebut, peneliti mencoba mengembangkan media pembelajaran dengan Macromedia Flash dengan judul penelitian "Pengembangan Macromedia Flash Berbasis Keterampilan Berpikir Kritis Pada Materi Cuaca Di Kelas III SD Muhammadiyah 4 Jakarta". Penelitian ini berupaya untuk mengenalisis mengenai pengembangan Macromedia Flash sebagai alat untuk mengembangkan kemampuan berpikir kritis peserta didik terutama dalam pembelajaran mengenai cuaca, kelayakan dari penggunaan Macromedia Flash sebagai alat untuk mengembangkan kemampuan berpikir kritis peserta didik terutama dalam pembelajaran mengenai cuaca, dan respon pendidik dan peserta didik dalam Macromedia Flash sebagai alat untuk mengembangkan kemampuan berpikir kritis peserta didik terutama dalam pembelajaran mengenai cuaca.

\section{METODE PENELITIAN}

Peneliti menggunakan metode penelitian dan pengembangan atau Research and Development (R\&D). Sugiyono dalam (Kamal, 2020)mengksplorasi lebih jauh mengenai metode ini dengan menyatakan bahwa metode R\&Dadalah suatu metode penelitian yang digunakan untuk menghasilkan suatu hal atau produk tertentu yang dapat diuji kefektifannya dalam mengatasi permasalahan yang hendak diselesaikan. Dalam perkembangannya, untuk menghasilkan suatu produk diperlukan analisis kebutuhan untuk melihat apakah produk tersebut akan efektif berfungsi digunakan oleh masyarakat. Riset dan penelitian berupaya untuk menjawab pertanyaan tersebut. Pendekatan yang digunakan oleh peneliti 2 jenis pendekatan, yaitu kuantitatif dan kualitatif(Sumarni, 2019). Pendekatan kualitatif banyak menggunakan data deskriptif, seperti wawancara dan kritik atau saran yang diberikan oleh ahli media dan ahli materi terhadap media yang tengah dikembangkan oleh peneliti(Zaluchu, 2020). Sedangkan pendekatan kuantitatif yang banyak menggunakan angka-angka, seperti hasil angket dan validasi yang telah diberikan oleh ahli media, ahli materi, dan uji coba yang diuji kepada guru dan peserta didik selaku objek penelitian terhadap media yang tengah dikembangkan oleh peneliti.Subjek penelitian dalam jurnal ini adalah siswa SDS Muhammadiyah 4 Jakarta kelas III Berjumlah 12 orang. Dalam perkembangannya, model penelitian Rnd memiliki berbagai macam jenis seperti model 4D(Prayitno, 2017). Namun peneliti melihat bahwa model penelitian dan pengembangan ADDIE sebagai model penelitian dan pengembangan yang paling cocok dalam penelitian ini. Research and DevelopmentADDIE yang dikembangkan oleh Maribe Branch INI 5 tahapan, yakni Analisis, Desain, Pengembangan, Implementasi, dan Evaluasi(Cahyadi, 2019). 
3135 Pengembangan Macromedia Flash Berbasis Keterampilan Berpikir Kritis di Sekolah Dasar - Yulia Ulfa, Prima Mutia Sari

DOI: https://doi.org/10.31004/edukatif.v3i5.1235

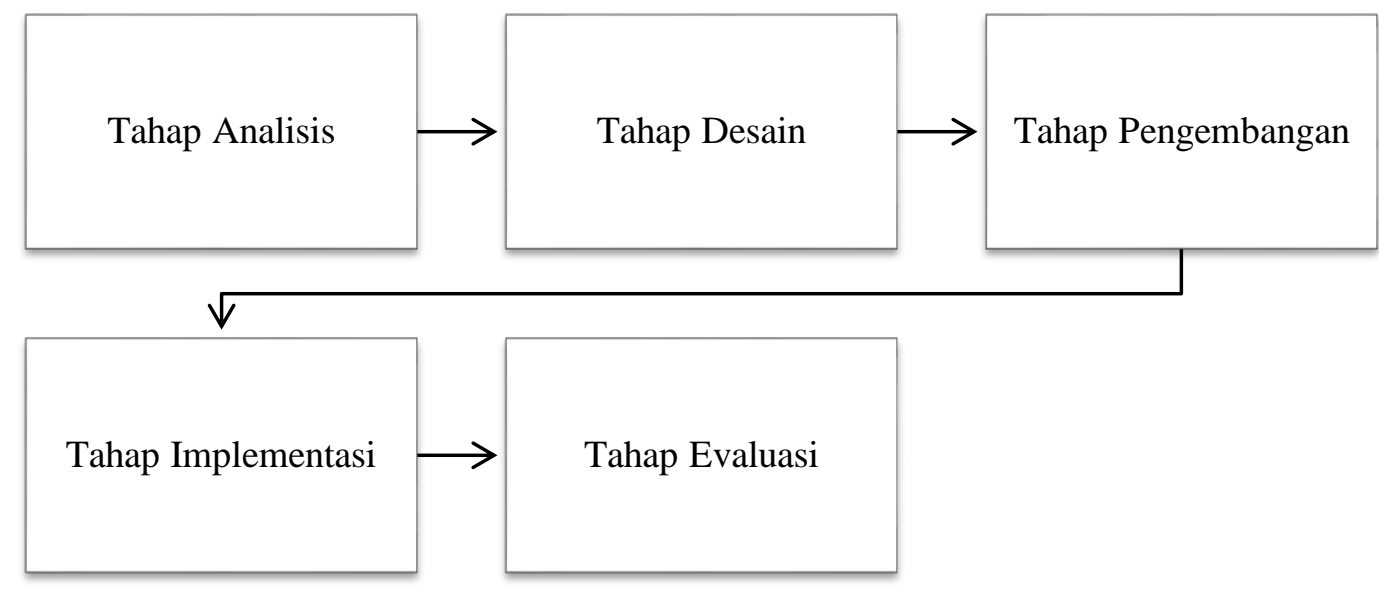

Gambar 1. Model R\&D ADDIE

Ada beberapa langkah penelitian yang akan dilakukan oleh peneliti. Pertama, tahap pendahuluan. Dalam tahap ini, peneliti melakukan observasi lapangan (analisis kebutuhan) guna mendapatkan informasi yang dibutuhkan. Tujuan yang hendak dicapai adalah menganalisis kebutuhan tenaga pendidik dan peserta didik terhadap media pembelajaran. Setelah itu, peneliti melakukan langkah kedua yaitu perencanaan pengembangan model. Pada tahap ini, peneliti mengembangkan Macromedia Flash berbasis keterampilan berpikir kritis dalam pembelajaran IPA materi Cuaca dengan menggunakan model pengembangan ADDIE. Berikut ini merupakan tahapan-tahapan penelitian dan pengembangan Macromedia Flash berbasis keterampilan berpikir kritis pada materi Cuaca.

Pertama, analisis untuk mengetahui sejauh mana kebutuhan guru dan peserta didik untuk mengatasi kesulitan belajar di kelas menggunaan media pembelajaran. Analisis kebutuhan peserta didik yaitu, meliputi karakteristik peserta didik dan kebutuhan bersama menjadi sasaran penggunaan media pembelajaran Macromedia Flash berbasis keterampilan berpikir kritis pada materi Cuaca. Peneliti juga menganalisiskarakter peserta didik, tingkat perkembangan kognitif, kemampuan bersosialisasi dan proses belajar-mengajar yang dilakukan;Kedua, peneliti melakuan perencanaan atau desain untuk membuat aplikasi dari awal hingga akhir berbasis keterampilan berpikir kritis; Ketiga, proses pengembangan ketika perencaan yang telah dibuat kemudian direalisasikan dalam bentuk produk yang dapat diuji. Peneliti mengumpulkan, menyusun, dan merancang materi berbasis keterampilan berpikir kritis yang dimuat ke dalam media, merancang pembuatan desain berupa pengumpulan gambar, background, tombol, video, dan suara kedalam software Macromedia Flash mengacu pada storyboard yang telah dibuat oleh peneliti. Produk yang telah selesai dikembangkan maka akan diuji validasi oleh dosen ahli media dan dosen ahli materi dengan tujuan merevisi media pembelajaran yang akan diuji; Keempat, proses implementasi yaitu ketika produk yang telah didesain kemudian diuji keberhasilannya. Setelah itu,, masuk ke tahapan evaluasi dengan membagikan angket kepada responden untuk mengetahui tanggapan mengenai produk yang telah dikembangkan dengan Macromedia Flash berbasis keterampilan berpikir kritis pada materi Cuaca.

Setelah melakukan tahap perencanaan pengembangan model, adalah memastikan terimplementasinya validasi, evaluasi, dan revisi. Menurut (Apriansyah, 2020), lalidasi dari penelitian pengembangan ini berupa kegiatan untuk menilai dan menganalisa kelayakan terhadap produk berupa media pembelajaran yang telah dikembangkan. Dalam proses ini, dilibatkan dosen ahli dalam bidang materi maupun bidang media. Uji validasi dilakukan dengan menggunakan lembar instrument berupa skala penilaian yang diberikan kepada validator untuk menganalisis mengenai produk yang akan digunakan. Hasil dari validasi ini berupa kelayakan produk yang dikembangakan serta saran, masukan, maupun komentar dari dosen ahli untuk mengetahui kelebihan dan kekurang dari media yang akan dikembangkan. Minimal hasil yang harus diperoleh layak untuk 
3136 Pengembangan Macromedia Flash Berbasis Keterampilan Berpikir Kritis di Sekolah Dasar - Yulia Ulfa, Prima Mutia Sari

DOI: https://doi.org/10.31004/edukatif.v3i5.1235

diujicoba, dengan ini peneliti dapat menlajutkan ke tahap selanjutnya.Adapun instrumen kisi-kisi untuk ahli materi, ahli media, validasi media oleh guru, dan uji coba media kepada siswa.

Tabel 1

Instrumen kisi-kisi validasi dan uji coba

Kisi - Kisi Instrumen

Instrumen

Aspek

\begin{tabular}{cl}
\hline \multirow{4}{*}{ Validasi oleh Ahli Materi } & Materi \\
\cline { 2 - 2 } & Pembelajaran \\
\cline { 2 - 2 } & Evaluasi \\
\cline { 2 - 2 } Validasi oleh Ahli Media & Tebahasaan \\
\cline { 2 - 2 } & Pempilan \\
\hline \multirow{2}{*}{ Uji Kelayakan oleh Pendidik } & Materi dan \\
\cline { 2 - 2 } & Pembelajaran \\
\hline \multirow{2}{*}{ Uji Coba oleh Siswa } & Pedia \\
\cline { 2 - 2 } & Media \\
\hline
\end{tabular}

Tabel 2

Keterangan skor pada setiap instrumen

Skala Skor Instrumen

Kriteria

Skor

\begin{tabular}{ll}
\hline Sangat Baik & 5 \\
\hline Baik & 4 \\
\hline Cukup & 3 \\
\hline Kurang Baik & 2 \\
\hline Sangat Kurang Baik & 1 \\
\hline
\end{tabular}

Kemudian, menurut (Optiana, 2019) analisis data hasil validasi tersebut kemudian dianalisis lebih lanjut menggunakan rumus berikut ini:

$$
\begin{array}{ll} 
& \mathrm{NP}=\frac{R}{S M} \times 100 \% \\
& \quad \text { Keterangan : } \\
\mathrm{NP} & : \text { Nilai persen yang dicari atau diharapkan } \\
\mathrm{R} & : \text { Skor yang diperoleh } \\
\mathrm{SM} & : \text { Skor maksimal (total skor) }
\end{array}
$$

Rumus tersebut membantu peneliti dalam menentukan taraf keberhasilan pengembangan media dan revisi. Adapun tabel kriteria kelayakannya, sebagai berikut:

Tabel 3

Skala Kelayakan

\begin{tabular}{lc}
\hline \multicolumn{1}{c}{ Kategori } & $\begin{array}{c}\text { Tingkat Pencapaian } \\
(\boldsymbol{\%})\end{array}$ \\
\hline Sangat Layak & $76 \%-100 \%$ \\
\hline Layak & $56 \%-75 \%$ \\
\hline Kurang Layak & $40 \%-55 \%$ \\
\hline Tidak Layak & $0 \%-39 \%$ \\
\hline
\end{tabular}


3137 Pengembangan Macromedia Flash Berbasis Keterampilan Berpikir Kritis di Sekolah Dasar - Yulia Ulfa, Prima Mutia Sari

DOI: https://doi.org/10.31004/edukatif.v3i5.1235

Evaluasi dilakukan untuk menentukan kelebihan dan kekurangan dari produk yang telah dikembangkan dengan melihat hasil dari uji validasi oleh para ahli dan penilaian produk oleh guru dan uji coba pada peserta didik berdasarkan hasil kelayakan.Dalam hal ini peneliti menggunakan google form untuk melakukan evaluasi. Sedangkan, revisi produk dilakukan apabila peneliti telah mengetahui kelemahan dan kelebihan dari produk yang telah di uji validasi oleh dosen ahli.Revisi produk dilakukan berdasarkan hasil uji validasi dengan mempertimbangkan kritik, saran dan masukan dari validator.

\section{HASIL DAN PEMBAHASAN PENELITIAN}

Media pembelajaran Macromedia Flash berbasis keterampilan berpikir kritis dikembangan dengan menggunakan model ADDIE dengan melalui lima tahapan, yaitu:

Tahap Analisis (Analysis). Pada tahap analisis peneliti menganalisis kebutuhan dan karakteristik dengan melakukan observasi, peneliti menemukan bahwa proses pembelajaran di kelas III yang dilakukan oleh guru terkesan monoton, pembelajaran hanya menggunakan video berupa slide Powerpoint sederhana. Guru mengalami kendala dalam mengembangkan media pembelajaran dalam bentuk teknologi sehingga media pembelajaran yang digunakan kurang inovatif sehingga pembelajaran kurang menarik bagi siswa dan siswa cepat merasa bosan ketika proses pembelajaran berlangsung. Hal ini berimplikasi pada rendahnya keterampilan berpikir kritis pada siswa. Setelah itu peneliti melakukan analisis materi dan soal dalam tahap ini penyusunan materi dan pertanyaan yang dapat dijawab oleh peserta didik yang ada di media pembelajaran Macromedia Flash untuk membangun dan mengembangkan keterampilan berpikir kritis ini, dibuat dengan melihat dari kompetensi dasar dan indikator sebagai acuannya, untuk diambil sebagai dasar penyusunan materi soal pada media pembelajaran. kemudian peneliti melakukan analisis alat dan pembuatan media. Dalam hal ini, peneliti memerlukan software dan hardware yang sesuai.Software yang digunakan untuk bertujuan membangun media pembelajaran yang dikehendaki dengan menggunakan beberapa aplikasi berikut ini: (1) Aplikasi Macromedia Flash Professionaluntuk membuat media pembelajaran lebih interaktif; (2) Website https://www.google.com/ untuk mengunduh gambar, foto, dan ikon yang akan digunakan didalam media pembelajaran; dan Aplikasi Powerpoint untuk mendesain dari media pembelajaran, mendesain tombol dan menghapus latar belakang background. Selain itu, peneliti juga melibatkan berbagai hardware dalam proses ini.

Tahap Desain (Design). Dalam tahap ini, peneliti melakukan pembuatan flowchart, storyboard, materi, penyusunan soal dan gambar maupun tombol yang dimasukkan kedalam media pembelajaran melalui Macromedia Flash 8 Professional.

Flowchart merupakan gambaran alur program dari media pembelajaran Macromedia Flash berbasis keterampilan berpikir kritis. Sedangkan storyboardadalahgambaran menyeluruh dari media pembelajaran yang telah didesain. Storyboardberguna untuk memudahkan dalam proses pembuatan media. Dalam proses penyusunan soal, peneliti merumuskan soal berbasis keterampilan berpikir kritis sesuai kompetensi dasar sekaligus pengembangan indicator yang sesuai dengan pembelajaran masuk kedalam ranah kognitif $\mathrm{C} 4$ (menganalisis), C5 (mengevaluasi), dan C6 (mencipta). Kemudian peneliti melakukan pengumpulan gambar, background, suara, dan tombol.

Tahap pengembangan(development), Langkah pertama dalam membuat media pembelajaran Macromedia Flash adalah dengan membuat tampilan cover dengan menampilkan animasi simbol cuaca dan judul media pembelajaran. Lalu membuat data identitas siswa sebagai pengguna, dan menempatkan tombol start, pembuatan tampilan doa sebelum belajar, kemudian pembuatan berdoa sebelum belajar, kemudian terakhir membuat menu utama yang berisikan tombol-tombol navigasi untuk masuk ke menu lainnya. 


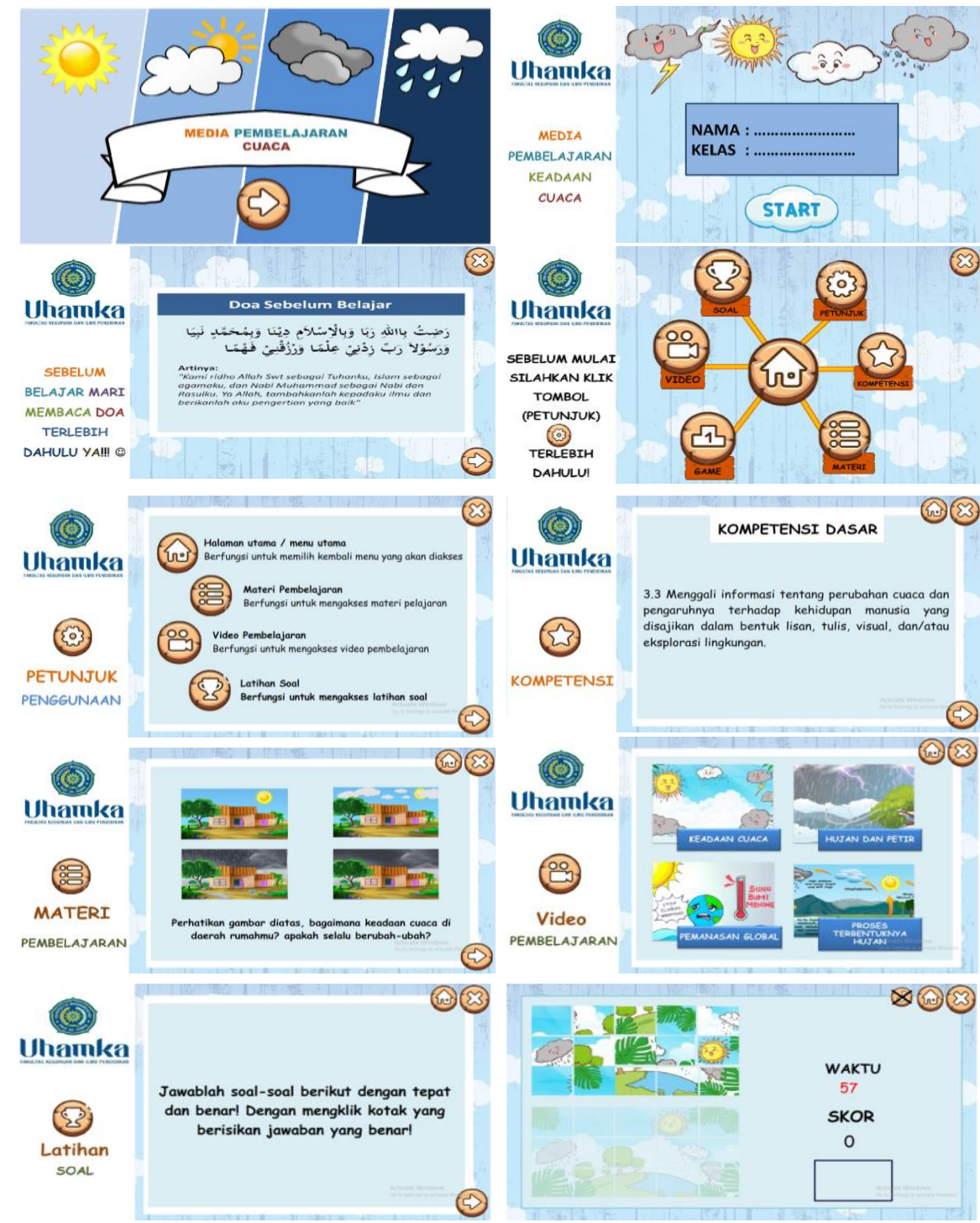

\section{Gambar 2. Hasil pengembangan Macromedia Flash (sumber pribadi)}

Tahap Implementasi (Implementation). Setelah melakukan tahap pengembangan media pembelajaran, pada tahap ini dilakukannya tahap validasi oleh ahli dan diujicobakan kepada guru dan peserta didik kelas III. Pada tahap implementasi juga dilakukan penyebaran angket untuk mendapatkan umpan balik dari produk media pembelajaran yang dikembangkan. Hasil yang didapatkan adalah media pembelajaran Macromedia Flash pada materi Cuaca sangat efektif dalam pembelajaran serta dapat membuat peserta didik berpikir kritis.

Tahap Evaluasi (Evaluation). Setelah tahap implementasi dilakukan dengan memberikan media pembelajaran Macromedia Flash kepada validator ahli, guru, dan siswa, tahap selanjutnya yaitu melakukan evaluasi terhadap media pembelajaran yang telah diuji coba oleh guru dan peserta didik. Evaluasi itulah yang dijadikan acuan standar untuk memperbaiki kualitas media yang digunakan.. Pada evaluasi produk akhir dilakukan agar media pembelajaran yang telah dikembangkan dapat digunakan dengan mudah oleh guru dan siswa.

Hasil uji validasiahli materi ditunjukan pada table berikut ini: 
3139 Pengembangan Macromedia Flash Berbasis Keterampilan Berpikir Kritis di Sekolah Dasar - Yulia Ulfa, Prima Mutia Sari

DOI: https://doi.org/10.31004/edukatif.v3i5.1235

Tabel 4

Tabel penilaian kelayakan media oleh ahli materi 1

\begin{tabular}{lll}
\hline Aspek & $\begin{array}{c}\text { Hasil Validasi Ahli Materi } \\
\text { Persentase }\end{array}$ & $\begin{array}{l}\text { Kriteria } \\
\text { Kelayakan }\end{array}$ \\
\hline Materi & $88.00 \%$ & Sangat Layak \\
\hline Pembelajaran & $76.60 \%$ & Sangat Layak \\
\hline Evaluasi & $80.00 \%$ & Sangat Layak \\
\hline Kebahasaan & $100 \%$ & Sangat Layak \\
\hline $\begin{array}{l}\text { Rata }- \text { Rata } \\
\text { Persentase }\end{array}$ & $\mathbf{8 4 . 0 0 \%}$ & Sangat Layak \\
\hline
\end{tabular}

Tabel 5

Tabel penilaian kelayakan media oleh ahli materi 2

\begin{tabular}{lcc}
\hline Aspek & $\begin{array}{c}\text { Hasil Validasi Ahli Materi } \\
\text { Persentase }\end{array}$ & $\begin{array}{l}\text { Kriteria } \\
\text { Kelayakan }\end{array}$ \\
\hline Materi & $84.00 \%$ & Sangat Layak \\
\hline Pembelajaran & $80.00 \%$ & Sangat Layak \\
\hline Evaluasi & $80.00 \%$ & Sangat Layak \\
\hline Kebahasaan & $80.00 \%$ & Sangat Layak \\
\hline $\begin{array}{l}\text { Rata }- \text { Rata } \\
\text { Persentase }\end{array}$ & $\mathbf{8 1 . 3 3 \%}$ & Sangat Layak \\
\hline
\end{tabular}

Tabel 6

Tabel penilaian kelayakan media oleh ahli materi $1 \&$ ahli materi 2

\begin{tabular}{lcc}
\hline Aspek & $\begin{array}{c}\text { Hasil Validasi Ahli Materi } \\
\text { Persentase }\end{array}$ & $\begin{array}{l}\text { Kriteria } \\
\text { Kelayakan }\end{array}$ \\
\hline Materi & $86.00 \%$ & Sangat Layak \\
\hline Pembelajaran & $78.33 \%$ & Sangat Layak \\
\hline Evaluasi & $80.00 \%$ & Sangat Layak \\
\hline Kebahasaan & $90.00 \%$ & Sangat Layak \\
\hline $\begin{array}{l}\text { Rata - Rata } \\
\text { Persentase }\end{array}$ & $\mathbf{8 2 . 6 6 \%}$ & Sangat Layak \\
\hline
\end{tabular}

Kualitas media pembelajaran dianalisis dari aspek materi sebesar $86.00 \%$ yang mengindikasikan bahwa materi yang disuguhkan sangat layak. Dianalisis dari aspek pembelajaran, hasilnya yaitu $78.33 \%$ yang mengindikasikan bahwa materi yang disuguhkan sangat layak. Dianalisis dari aspek evaluasi hasilnya $80.00 \%$ dengan kategori sangat layak, dan ditinjau dari aspek bahasa sebesar 90.00\% dikategorikan sangat layak. Maka kualitas media pembelajaran hasil validasi oleh oleh kedua ahli materi diperoleh dengan rata-rata presentase keseluruhan adalah $82.66 \%$ dengan kategori sangat layak.

Peneliti juga melakukan uji validasi ahli media. Media pembelajaran diujikan kepada ahli media sebelum digunakan oleh uji coba siswa kelas III.Hal ini dilakukan agar kekurangan dalam media pembelajaran dapat diperbaiki lagi sebelum sampai kepada uji coba siswa kelas III.Aspek yang diajukan adalah aspek tampilan, dan aspek pemrograman. 
3140 Pengembangan Macromedia Flash Berbasis Keterampilan Berpikir Kritis di Sekolah Dasar - Yulia Ulfa, Prima Mutia Sari

DOI: https://doi.org/10.31004/edukatif.v3i5.1235

Tabel 7

Tabel penilaian kelayakan media oleh ahli media

\begin{tabular}{lcc}
\hline Aspek & $\begin{array}{c}\text { Hasil Validasi Ahli Media } \\
\text { Kriteria } \\
\text { Kelayakan }\end{array}$ \\
\hline Tampilan & $80.00 \%$ & Sangat Layak \\
\hline Pemrograman & $80.00 \%$ & Sangat Layak \\
\hline $\begin{array}{l}\text { Rata - Rata } \\
\text { Persentase }\end{array}$ & $\mathbf{8 0 . 0 0 \%}$ & Sangat Layak \\
\hline
\end{tabular}

Kualitas media pembelajaran dianalisis dari aspek tampilan sebesar $80.00 \%$ dengan kategori sangat layak. Dianalisis dari aspek pemrograman sebesar $80.00 \%$ dengan kategori sangat layak. Secara keseluruhan kualitas media pembelajaran hasil validasi oleh ahli media diperolehrata-rata presentase keseluruhan adalah $80.00 \%$ dengan kategori sangat layak.

Peneliti selanjutnya berfokus melakukan penilaian terhadap efektivitas media. Ada beberapa tahapan yang dilakukan. Dalam tahap implementasi ditemukan penilaian respon guru yaitu:

Tabel 8

Tabel penilaian respon oleh guru

\begin{tabular}{lcc}
\hline Aspek & \multicolumn{2}{c}{ Hasil Respon oleh Guru } \\
Persentase & $\begin{array}{l}\text { Kriteria } \\
\text { Kelayakan }\end{array}$ \\
\hline Tampilan & $94.28 \%$ & Sangat Layak \\
\hline Pemrograman & $95.00 \%$ & Sangat Layak \\
\hline $\begin{array}{l}\text { Rata - Rata } \\
\text { Persentase }\end{array}$ & $\mathbf{9 4 . 6 6 \%}$ & Sangat Layak \\
\hline
\end{tabular}

Berdasarkan hasil respon guru terhadap media pembelajaran Macromedia Flash berbasis keterampilan berpikir kritis, diketahui presentase tertinggi pada setiap aspeknya adalah aspek pembelajaran, yaitu 95.00\% dengan kategori sangat layak, dan ditinjau dari aspek media sebesar $94.28 \%$ dengan kategori sangat layak.Maka rata-rata presentase keseluruhan adalah $94.66 \%$ dengan kategori sangat layak.

Dalam tahap implementasi ditemukan penilaian respon peserta didik yaitu:

Tabel 9

Tabel hasil penilaian uji coba siswa kelas III di SD Muhammadiyah 4 Jakarta Hasil Uji Coba Siswa

\begin{tabular}{lll} 
Aspek & Persentase & $\begin{array}{l}\text { Kriteria } \\
\text { Kelayakan }\end{array}$ \\
\hline Pembelajaran & $94.16 \%$ & Sangat Layak \\
\hline Media & $93.66 \%$ & Sangat Layak \\
\hline $\begin{array}{l}\text { Rata }- \text { Rata } \\
\text { Persentase }\end{array}$ & $\mathbf{9 4 . 0 0 \%}$ & Sangat Layak \\
\hline
\end{tabular}

Berdasarkan hasil uji coba siswa siswa kelas III diketahui presentase tertinggi pada setiap aspeknya adalah aspek pembelajaran, yaitu $94.16 \%$ dengan kategori sangat baik yang meliputi indikator kemudahan pemahaman, kemandirian belajar dan keaktifan dalam belajar. Sedangkan presentase pada aspek media dengan presentase $93.66 \%$ dengan kategori sangat baik, yang meliputi indikator minat macromedia flash, penyajian macromedia flash. Dengan demikian, secara keseluruhan hasil dari penilaian media pembelajaran diuji coba kepada siswa diperoleh rata-rata presentase keseluruhan adalah $94.00 \%$ dengan kategori sangat baik dengan jumlah keseluruhan skor yang diperoleh siswa, yaitu 846. Sehingga dapat dikatakan bahwa media 


\section{Pengembangan Macromedia Flash Berbasis Keterampilan Berpikir Kritis di Sekolah Dasar - Yulia}

Ulfa, Prima Mutia Sari

DOI: https://doi.org/10.31004/edukatif.v3i5.1235

pembelajaran ini layak digunakan sebagai media pembelajaran dalam pembelajaran IPA mengenai cuaca untuk meningkatkan kemamuan berpikir kritis.

Berdasarkan hasil penelitian dari ahli materi diperoleh penilaian presentase tertinggi, yaitu pada aspek bahasa dengan presentase $90.00 \%$ yang mengindikasikan bahwa bahasa merupakan aspek yang menonjol dalam media macromedia flash ini.Sedangkan aspek lainnya yang berada pada posisi rata-rata ditempati oleh aspek materi yang mendapatkan hasil rata-rata presentase sebesar $86.00 \%$ yang mengindikasikan secara materi sudah sangat layak. Aspek evaluasi mendapatkan presentase $80.00 \%$ yang mengindikasikan secara evaluasi sudah sangat layak. Aspek pembelajaran mendapatkan presentase sebesar $78.33 \%$ yang mengindikasikan secara pembelajaran sudah sangat layak. Dengan ini secara keseluruhan aspek pada penilaian oleh ahli materi mendapatkan hasil presentase $82.66 \%$ dengan kategori sangat layak.Pada penilaian oleh ahli media, terdapat dua aspek yang dinilai, yaitu dari aspek tampilan dan pemrograman.Untuk aspek tampilan mendapatkan hasil rata-rata presentase, yaitu $80.00 \%$ dengan kategori sangat layak.Sedangkan aspek pemrograman mendapatkan hasil rata-rata presentase, yaitu $80.00 \%$ dengan kategori sangat layak.Dengan demikian secara keseluruhan aspek pada penilaian oleh ahli media mendapatkan hasil presentase $80.00 \%$ dengan kategori sangat layak.Berdasarkan hasil respon guru terhadap media pembelajaran Macromedia Flash berbasis keterampilan berpikir kritis, diketahui presentase tertinggi pada setiap aspeknya adalah aspek pembelajaran, yaitu $95.00 \%$ dengan kategori sangat layak, dan ditinjau dari aspek media sebesar $94.28 \%$ dengan kategori sangat layak.Maka rata-rata presentase keseluruhan adalah $94.66 \%$ dengan kategori sangat layak. Berdasarkan hasil uji coba siswa siswa kelas III diketahui presentase tertinggi pada setiap aspeknya adalah aspek pembelajaran, yaitu $\mathbf{9 4 . 1 6 \%}$ dengan kategori sangat baik yang meliputi indikator kemudahan pemahaman, kemandirian belajar dan keaktifan dalam belajar.Sedangkan presentase terendah pada setiap aspeknya, yaitu aspek media dengan presentase $93.66 \%$ dengan kategori sangat baik, yang meliputi indikator minat macromedia flash, penyajian macromedia flash.Maka rata-rata presentase keseluruhan adalah $94.00 \%$ dengan kategori sangat layak. Sehingga dapat dikatakan bahwa media pembelajaran ini layak digunakan oleh siswa dan guru dalam proses pembelajaran khususnya pada materi cuaca di kelas III.

Hasil dari penelitian ini juga sejalan dengan hasil penelitian yang dilakukan oleh(Darma \& Putra, 2020) hasil pengembangan Macromedia flash yang memperoleh hasil penelitian dengan rata-rata presentase validator ahli materi sebesar $88,71 \%$, rata-rata presentase ahli media sebesar $8,75 \%$,rata-rata presentase uji coba sebesar 87,91\%. Pada penelitian Macromedia Flash berbasis keterampilan berpikir kritis pada materi cuaca memperoleh kualitas produk sangat baik, Sehingga dapat dikatakan bahwa media pembelajaran ini layak digunakan oleh siswa dan guru dalam proses pembelajaran khususnya pada materi cuaca di kelas III dan berdasarkan karakteristik soal berpikir kritis, yaitu memberikan penjelasan sederhana, membangun keterampilan dasar, melakukan dan mempertimbangkan hasil deduksi dan induksi, memberikan penjelasan lebih lanjut, dan mengatur strategi dan taktik, dimana peserta didik diharapkan dapat menerapkan konsepkonsep pembelajaran dikelas untuk menyelesaikan suatu masalah (Wijayanti \& Siswanto, 2020).Kegiatan pembelajaran dengan menggunakan Macromedia flashini layak digunakan dandapat digunakan saat pembelajaran berlangsung ataupun mandiri digunakan oleh peserta didik, sehingga pembelajaran dapat lebih efektif dan praktis dalam proses pembelejaran(Rahmi et al., 2019).Selain itu, pernyataan tersebut diperkuat oleh (Hendi et al., 2020)menyatakan bahwa dengan menggunakan Macromedia flashdapat membantu siswa agar mampu untuk berpikir dalam menghubungkan antara konsep dengan hubungan dunia nyata sehingga dapat memecahkan suatu permasalahan.Melalui media pembelajaran Macromedia Flash berbasis keterampilan berpikir kritispeserta didik mampu menganalisis ataupun menalar, mengambil keputusan terkait pemecahan masalah, serta mengevaluasi melalui soal evaluasi yang telah dikembangkan yang cenderung berbasis keterampilan berpikir kritis(Fridanianti et al., 2018)

Macromedia Flash berbasis keterampilan berpikir kritis, memiliki kelebihan dan kekurangan. Kelebihan dari media ini adalah: Macromedia flash berbasis keterampilan berpikir kritis merupakan media pembelajaran 
3142 Pengembangan Macromedia Flash Berbasis Keterampilan Berpikir Kritis di Sekolah Dasar - Yulia Ulfa, Prima Mutia Sari

DOI: https://doi.org/10.31004/edukatif.v3i5.1235

yang bersifat tidak terbatas ruang dan waktu, macromedia flash berbasis keterampilan berpikir kritis merupakan inovasi media pembelajaran untuk materi Cuaca di kelas III, di dalam macromedia flash berbasis keterampilan berpikir kritis terdapat menu permainan, sehingga proses pembelajaran lebih menyenangkan, macromedia flash berbasis keterampilan berpikir kritis merupakan media pembelajaran yang bersifat tidak terbatas ruang dan waktu, dan macromedia flash berbasis keterampilan berpikir kritis merupakan inovasi media pembelajaran pada materi Cuaca di kelas III. Sedangkan kekurangan dari media ini mengingat tidak seluruh siswa memiliki laptop, atau notebook, maupun netbook. Hal-hal yang perlu disempurnakan kembali animasi gambar, design, dan pengembangan macromedia flash yang dapat dijadikan menjadi aplikasi yang dapat dibuka melalui android atau smartphone.

\section{KESIMPULAN}

Beberapa kesimpulan dapat dirumuskan dalam penelitian ini sebagai berikut: (1) Pengembangan media pembelajaran Macromedia flash berbasis keterampilan berpikir kritis menggunakan model ADDIEyang diuji cobakan kepada guru dan siswa kelas III SD Muhammadiyah 4 Jakarta. Hasil produk akhir, yaitu file dengan format .exe atau application, yang terdiri dari materi cuaca dengan submateri keadaaan cuaca, perubahan cuaca, dan dan pengaruh perubahan cuaca terhadap kehidupan manusia. (2) Hasil dari validasi ahli materi dan ahli media didapatkan predikatdengan kategori sangat layak. (3) Ujicoba pendidik dan peserta didik terhadap media pembelajaran dilihat dari hasil angket yang diberikan melalui google formulir yang telah diberikan mendapatkan predikat dengan kategori sangat layak. (4) Media pembelajaran Macromedia flash berbasis keterampilan berpikir kritis pada materi Cuaca di kelas III, dapat digunakan oleh peserta didik didalam kelas, dirumah, maupun di dalam labkomputer. (5) Media pembelajaran Macromedia flash berbasis keterampilan berpikir kritis dapat digunakan oleh guru sebagai salah satu sumber, alat media mengajar tambahan, maupun motivasi guru dalam membuat media pembelajaran selain menggunakan slide powerpoint yang sudah sering digunakan.

\section{UCAPAN TERIMA KASIH}

Peneliti mengucapkan terima kasih kepada Allah SWT yang telah memberikan kekuatan dan kesehatan, kepada orang tua, keluarga, kepada ibu Prima Mutia Sari selaku dosen pembimbing, teman-teman yang telah mendukung penelitian ini, serta siswa-siswi, dan guru-guru SD Muhammadiyah 4 Jakarta.

\section{DAFTAR PUSTAKA}

Amalia, A. R., Purwati, H., \& Nursyahidah, F. (2020). Pengembangan Media Pembelajaran Berbasis PMRI Untuk Meningkatkan Kemampuan Berpikir Kritis Siswa SMP. Imajiner: Jurnal Matematika Dan Pendidikan Matematika. https://doi.org/10.26877/imajiner.v2i4.5883

Apriansyah, M. R. (2020). Pengembangan Media Pembelajaran Video Berbasis Animasi Mata Kuliah Ilmu Bahan Bangunan Di Program Studi Pendidikan Teknik Bangunan Fakultas Teknik Universitas Negeri Jakarta. Jurnal PenSil, 9(1), 9-18. https://doi.org/10.21009/jpensil.v9i1.12905

Cahyadi, R. A. H. (2019). Pengembangan Bahan Ajar Berbasis Addie Model. Halaqa: Islamic Education Journal, 3(1), 35. https://doi.org/10.21070/halaqa.v3i1.2124

Darma, Y., \& Putra, S. R. S. (2020). Pengembangan Media Pembelajaran Berbasis Macromedia Flash Bermuatan Problem Posing terhadap Kemampuan Pemecahan Masalah Matematis Mosharafa : Jurnal Pendidikan Matematika National Council of Teachers of Mosharafa : Jurnal Pendidikan Matematika. 9 , 323-334.

Daroes, O. J., Wibowo, D. C., \& Susanti, S. (2020). Analisis kemampuan berpikir kritis siswa pada mata pelajaran matematika. Jurnal Pendidikan Matemtika, 2(2), 242-254.

http://jurnal.stkippersada.ac.id/jurnal/index.php/jpimat/article/view/889/pdf

Edukatif : Jurnal Ilmu Pendidikan Vol 3 No 5 Tahun 2021 p-ISSN 2656-8063 e-ISSN 2656-8071 
3143 Pengembangan Macromedia Flash Berbasis Keterampilan Berpikir Kritis di Sekolah Dasar - Yulia Ulfa, Prima Mutia Sari

DOI: https://doi.org/10.31004/edukatif.v3i5.1235

Fridanianti, A., Purwati, H., \& Murtianto, Y. H. (2018). Analisis Kemampuan Berpikir Kritis Dalam Menyelesaikan Soal Aljabar Kelas Vii Smp N 2 Pangkah Ditinjau Dari Gaya Kognitif Reflektif Dan Kognitif Impulsif. AKSIOMA : Jurnal Matematika Dan Pendidikan Matematika, 9(1), 11. https://doi.org/10.26877/aks.v9i1.2221

Haeruddin. (2017). Membuat Media Presentasi \& Game Quiz Berbasis Flash (Pertama). Deepublish.

Hendi, A., Caswita, C., \& Haenilah, E. Y. (2020). Pengembangan Media Pembelajaran Interaktif Berbasis Strategi Metakognitif untuk Meningkatkan Kemampuan Berpikir Kritis siswa. Jurnal Cendekia : Jurnal Pendidikan Matematika, 4(2), 823-834. https://doi.org/10.31004/cendekia.v4i2.310

Kamal, M. (2020). Research and Development ( R \& D ) Tadribat / Drill Madrasah Aliyah Class X Teaching Materials Arabic Language. Journal of History, Education, and Humanities, 4(1), 10-18. https://doi.org/10.36526/js.v3i2.e-ISSN

Lestari, Y. (2018). Penanaman nilai peduli lingkungan dalam pembelajaran ilmu pengetahuan alam. Jurnal Pendidikan Ke-SD-An, 4(2), 332-337. https://core.ac.uk/download/pdf/230377925.pdf

Maryam, M., Kusmiyati, K., Merta, I. W., \& Artayasa, I. P. (2020). Pengaruh Model Pembelajaran Inkuiri Terhadap Keterampilan Berpikir Kritis Siswa. Jurnal Pijar Mipa, 15(3), 206.

https://doi.org/10.29303/jpm.v15i3.1355

Munawwarah, M., Laili, N., \& Tohir, M. (2020). Keterampilan Berpikir Kritis Mahasiswa Dalam Memecahkan Masalah Matematika Berdasarkan Keterampilan Abad 21. Alifmatika: Jurnal Pendidikan Dan Pembelajaran Matematika, 2(1), 37-58. https://doi.org/10.35316/alifmatika.2020.v2i1.37-58

Mutmainnah, H., Uswatun, D. A., \& Wardana, A. E. (2020). Jurnal Inovasi Pendidikan dan Pembelajaran Sekolah Dasar Meningkatkan Pemahaman Konsep Perubahan Wujud Benda pada Pembelajaran Ilmu Pengetahuan Alam Melalui Metode Eksperimen di Sekolah Dasar. Jurnal Inovasi Pendidikan Dan Pembelajaran Sekolah Dasar P-ISSN. 2622-5069, E-ISSN. 2579-3403 Volume 4, Nomor 1, Juli 2020 Available Online at: Http://E-Journal.Unp.Ac.Id/Index.Php/Jippsd Meningkatkan, 4(1), 87-97. http://ejournal.unp.ac.id/index.php/jippsd\%0AMeningkatkan

Muttaqin, M. Z., Yuli, T., Siswono, E., \& Lukito, A. (2020). Pengembangan Multimedia Lectora Inspire Untuk Meningkatkan Kemampuan Berpikir Kritis Dalam Menyelesaikan Soal Cerita Bangun Ruang. 04(02), 495-511.

Nissa, S. F., \& Renoningtyas, N. (2021). EDUKATIF : JURNAL ILMU PENDIDIKAN Penggunaan Media Pembelajran Wordwall untuk Meningkatkan Minat dan Motivasi Belajar Siswa pada Pembelajaran Tematik di Sekolah Dasar. 3(5), 2854-2860.

Optiana, N. (2019). Pengembangan Panduan Penilaian Berbasis E-Portofolio Menggunakan Edmodo dalam pembelajaran praktikum fisika untuk Sekolah Menengah Atas. 6(2), 1-5. https://doi.org/10.12928/jrkpf.vxix.xxxx

Prayitno, T. A. (2017). Pengembangan Petunjuk Praktikum Mikrobiologi Program Studi Pendidikan Biologi. Biota, 3(1), 31. https://doi.org/10.19109/biota.v3i1.1041

Rahmi, M. S. M., Budiman, M. A., \& Widyaningrum, A. (2019). Pengembangan Media Pembelajaran Interaktif Macromedia Flash 8 pada Pembelajaran Tematik Tema Pengalamanku. International Journal of Elementary Education, 3(2), 178. https://doi.org/10.23887/ijee.v3i2.18524

Rohani. (2019). Diktat Media Pembelajaran. Fakultas Ilmu Tarbiyah Dan Keguruan Universitas Islam Negeri Sumatera Utara, 95.

Sholikha, S. N., \& Fitrayati, D. (2021). EDUKATIF : JURNAL ILMU PENDIDIKAN Integrasi Keterampilan 4C dalam Buku Teks Ekonomi SMA / MA. 3(5), 2402-2418.

Suhartini, S., \& Martyanti, A. (2017). Meningkatkan Kemampuan Berpikir Kritis pada Pembelajaran Geometri Berbasis Etnomatematika. Jurnal Gantang, 2(2), 105-111.

https://doi.org/10.31629/jg.v2i2.198

Edukatif : Jurnal Ilmu Pendidikan Vol 3 No 5 Tahun 2021 p-ISSN 2656-8063 e-ISSN 2656-8071 
3144 Pengembangan Macromedia Flash Berbasis Keterampilan Berpikir Kritis di Sekolah Dasar - Yulia Ulfa, Prima Mutia Sari

DOI: https://doi.org/10.31004/edukatif.v3i5.1235

Sumarni, S. (2019). Model penelitian dan pengembangan (RnD) lima tahap (MANTAP). Jurnal Penelitian Dan Pengembangan, 1(1), 1-33.

Syamsuddin, A. (2020). Penerapan Pendekatan Scientific dengan Metode Student Teams Achievement Divisio (STAD) untuk Meningkatkan Hasil Belajar Ilmu Pengetahuan Alam. 9(1), 113-122.

https://jurnaldidaktika.org/contents/article/view/16

Umryaty, T. (2020). Pengembangan Media Pembelajaran Ilmu Pengetahuan Alam Berbasis Metode Montessori di Sekolah Dasar Tuti Umryaty NIM F2211161002. Jurnal Pendidikan Dan Pembelajaran, 10(1), 1-8. https://jurnal.untan.ac.id/index.php/jpdpb/article/view/44317

Widowati, C., \& Purwanto, A. (2018). Pengembangan Media Pembelajaran Berbasis Prezi Dalam Meningkatkan Berpikir Kritis Siswa Pada Materi Sistem Pernapasan Makhluk Hidup. Proceedings Open Access Journal.

Wijayanti, R., \& Siswanto, J. (2020). Profil Kemampuan Berpikir Kritis Siswa SMA pada Materi Sumbersumber Energi. Jurnal Penelitian Pembelajaran Fisika, 11(1), 109-113. https://doi.org/10.26877/jp2f.v11i1.5533

Zaluchu, S. E. (2020). Strategi Penelitian Kualitatif dan Kuantitatif Di Dalam Penelitian Agama. Evangelikal: Jurnal Teologi Injili Dan Pembinaan Warga Jemaat, 4(1), 28. https://doi.org/10.46445/ejti.v4i1.167 